\title{
Interactions of Platinum Complexes Containing Cationic, Bicyclic, Nonplanar Piperidinopiperidine Ligands with Biological Nucleophiles
}

\begin{abstract}
Yousef Najajreh, ${ }^{\dagger}$ Yael Ardeli-Tzaraf,, Jana Kasparkova,${ }^{\S}$ Pavla Heringova, ${ }^{\S}$ Dmitri Prilutski, ${ }^{\#}$ Liliana Balter, ${ }^{\ddagger}$ Seba Jawbry, ${ }^{\ddagger}$ Elena Khazanov," Jose Manuel Perez, ${ }^{\perp}$ Yechezkel Barenholz," Viktor Brabec, ${ }^{\S}$ and Dan Gibson*,»,

Department of Medicinal Chemistry and Natural Products, Faculty of Pharmacy, Al-Quds University, Jerusalem, P.O. Box 20002, Palestine, Department of Medicinal Chemistry and Natural Products, School of Pharmacy, The Hebrew University of Jerusalem, P.O. Box 12065, Jerusalem 91120, Israel, Institute of Biophysics, Academy of Sciences of the Czech Republic, CZ-61265 Brno, Czech Republic, Interdepartmental Equipment Unit, Hadassah Medical School, The Hebrew University, Jerusalem 91120, Israel, Laboratory of Membrane and Liposome Research, Department of Biochemistry, Hadassah Medical School, The Hebrew University, P.O. Box 12272, Jerusalem 91120, Israel, and Departamento de Química Inorgánica, Facultad de Ciencias, Universidad Autónoma de Madrid, 28049 Madrid, Spain
\end{abstract}

Received March 1, 2006

The determination of the structures and DNA interactions and the reactions with GSH and ubiquitin of complexes of the general formula trans-[ $\mathrm{PtCl}_{2}(\mathrm{Am})($ pip-pip) $] \cdot \mathrm{HCl}$, where pip-pip is 4-piperidinopiperidine and $\mathrm{Am}$ is $\mathrm{NH}_{3}$, methylamine (MA), dimethylamine (DMA), $n$-propylamine (NPA), isopropylamine (IPA), $n$-butylamine (NBA), or cyclohexylamine (CHA), were performed. X-ray structures and NMR studies of the $\mathrm{NH}_{3}$ and MA complexes showed that both pip rings were in the chair conformation and that the second pip ring is fluxional. The DNA binding studies showed that these complexes bind to calf thymus DNA nearly an order of magnitutde more quickly than cisplatin and form covalent adducts that stabilize the double helix. The binding of the pip-pip complexes to DNA results in high unwinding angles $\left(\sim 30^{\circ}\right)$ and in the formation of $\sim 25 \%$ interstrand cross-links. The pip-pip complexes reacted with GSH more quickly than cisplatin and transplatin, and the rate of reaction decreased with increasing steric bulk of the ligand trans to the pip-pip. The reactions with ubiquitin resulted in monofunctional binding to Met1. Only the $\mathrm{NH}_{3}, \mathrm{MA}$, and DMA complexes reacted with ubiquitin in a slower and less efficient fashion than cisplatin.

\section{Introduction}

We have shown that trans- $\left[\mathrm{PtCl}_{2}(\mathrm{Am})(\right.$ pip-pip) $] \cdot \mathrm{HCl}^{a}$ complexes (Figure 1, right) are cytotoxic agents that are effective especially against cisplatin-resistant cancer cell lines. ${ }^{1}$ We have also shown that these complexes are significantly less toxic to mice than cisplatin. In vivo efficacy studies in nude mice bearing A2780 and A2780cisR tumors showed that they were less efficacious than cisplatin but did increase the life span of the mice by $79 \%$ for A2780 and $40 \%$ for A2780cisR compared with $160 \%$ and $59 \%$ for cisplatin. In the C-26 (colon cancer model) they were as active as cisplatin (104\% and $118 \%$, respectively). The anticancer activity of platinum agents is believed to be the result of their covalent binding to cellular DNA and their ability to distort the DNA structure. ${ }^{2-5}$ There are many ways in which the cells can respond to this distortion, including successful repair of the damaged DNA, which leads

* To whom correspondence should be addressed. Phone: 972-2-6758702. Fax: 972-2-675-7076. E-mail: gibson@md.huji.ac.il.

Al-Quds University.

$\div$ The Hebrew University of Jerusalem.

$\S$ Institute of Biophysics.

\# Interdepartmental Equipment Unit, Hadassah Medical School, The Hebrew University.

"Department of Biochemistry, Hadassah Medical School, The Hebrew University.

${ }^{\perp}$ Universidad Autónoma de Madrid.

${ }^{\infty}$ Affiliated with the David R. Bloom, Center for Pharmacy at The Hebrew University of Jerusalem, Israel.

${ }^{a}$ Abbreviations: GSH, glutathione; pip-pip, 4-piperidinepiperidine; pz, piperazine; pip, piperidine; DMF, dimethylformamide; ESIMS, electrospray ionization mass spectrometry; transplatin, trans-diamminedichloroplatinum(II), MA, methylamine; DMA, dimethylamine; NBA, $n$-butylamine; IPA, isopropylamine; CHA, cyclohexylamine; COSY, correlation spectroscopy; NOESY, nuclear Overhauser effect spectroscopy; HSQC, heteronuclear single qunatum correlation; HMBC, heternuclear multiple bond correlation FAAS, flameless atomic absorption spectroscopy; dien, diehtylenetriamine; ICL, interstrand cross-link; Ub, ubiquitin; CD, circular dichroism.
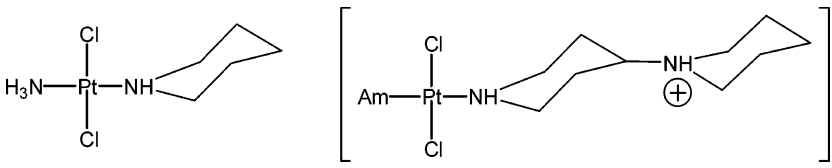

Figure 1. Nonclassical transplatinum complexes with nonplanar heterocyclic amine ligands: trans- $\left[\mathrm{PtCl}_{2}\left(\mathrm{NH}_{3}\right)\right.$ (pip)] (left) and trans$\left[\mathrm{PtCl}_{2}\right.$ (Am)(pip-pip)] $\cdot \mathrm{HCl}$ (right).

to the survival of the cell, and futile attempts to repair the damage that culminate in apoptosis. ${ }^{6-9}$ Thus, it is very important to study the interactions of the platinum complexes with DNA, including the binding kinetics and the distortions of the double helical structure that results from platination of the DNA.

Cisplatin forms mainly 1,2-GpG intrastrand cross-links (CLs), and transplatin forms mainly interstrand CLs. ${ }^{10,11}$ We have shown that trans-[ $\mathrm{PtCl}_{2}\left(\mathrm{NH}_{3}\right)$ (pip)] (Figure 1, left) forms stable 1,3-intrastrand CLs in double-helical DNA that distort the DNA. ${ }^{12}$ These adducts are not readily removed from DNA by the nucleotide excision repair system, and they were not readily recognized by HMG1 proteins. In addition, trans- $\left[\mathrm{PtCl}_{2}\left(\mathrm{NH}_{3}\right)\right.$ (pip)] is significantly more efficient than cisplatin in blocking DNA replication..$^{13}$ Some combinations of these DNA binding properties probably contribute to its ability to circumvent cisplatin resistance. trans-[ $\mathrm{PtCl}_{2}(\mathrm{Am})($ pip-pip) $] \cdot \mathrm{HCl}$ complexes have an additional piperidine ring that is positively charged (see Figure 1, right), and these additional structural features could significantly affect the DNA binding properties of the pip-pip complexes relative to those of the trans-[ $\mathrm{PtCl}_{2}\left(\mathrm{NH}_{3}\right)$ (pip)]. ${ }^{12,13}$

Platination of cellular DNA is only one of many competing platination reactions that take place after the platinum complexes enter the cell. ${ }^{14-16}$ In fact, only a small fraction of the intracellular platinum ends up on the DNA. This can be understood in terms of the very high affinity of divalent platinum to sulfur-containing ligands (cysteines and methionines) and to 

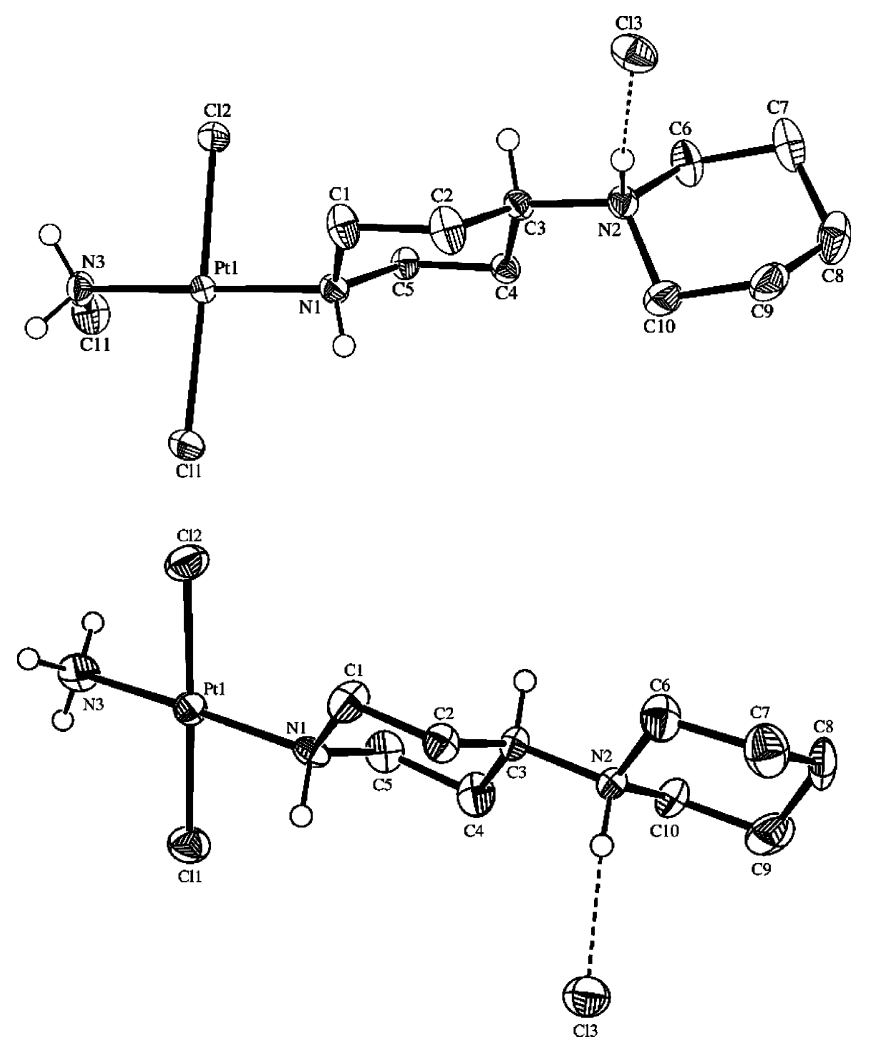

Figure 2. Molecular structure and atom labeling scheme of trans$\left[\mathrm{PtCl}_{2}\left(\mathrm{CH}_{3} \mathrm{NH}_{2}\right)\right.$ (pip-pip)] $\mathrm{HCl}$ (top) and of trans-[ $\mathrm{PtCl}_{2}\left(\mathrm{NH}_{3}\right)$ (pip-pip)] $\mathrm{HCl}$ (bottom). In both cases the dotted line represents the hydrogen bond between the counterion $(\mathrm{Cl} 3)$ and the $\mathrm{NH}$ proton on the second piperidine ring.

the 500- to 1000-fold excess of intracellular thiols (up to tens of $\mathrm{mM}$ ) relative to the intracellular platinum concentrations (low $\mu \mathrm{M}$ range). The binding of platinum complexes to intracellular sulfur nucleophiles can serve several functions. The most commonly accepted role of thiols, in this context, is to prevent the platinum complexes from reaching the DNA, and hence, the thiols act as detoxification agents. ${ }^{17,18}$ One way by which cells acquire resistance to cisplatin is by increasing production of cellular glutathione (GSH). ${ }^{19,20}$ Another possible role of intracellular proteins is chaperoning the $\mathrm{Pt}$ complexes and delivering them to the DNA. ${ }^{21-25}$ Therefore, it is important to study the formation and stability of protein $-\mathrm{Pt}$ adducts that are formed by methionine binding.

In this manuscript we describe the solid state and solution structural features of the trans-[ $\left[\mathrm{PtCl}_{2}(\mathrm{Am})(\right.$ pip-pip) $] \cdot \mathrm{HCl}$ complexes as well as their interactions with DNA including the binding kinetics and the distortions they confer to the ds-DNA. In addition, their interactions with GSH and with the model protein ubiquitin (Ub) are described.

\section{Results}

Structural Analysis of the trans-[PtCl $2(\mathrm{Am})($ pip-pip) $] \cdot \mathbf{H C l}$ Complexes Where Am $=\mathbf{N H}_{3}$, MA. X-ray Crystallography. The structures and labeling schemes of trans- $\left[\mathrm{PtCl}_{2}\left(\mathrm{NH}_{3}\right)\right.$ (pippip)] $\cdot \mathrm{HCl}$ and trans-[ $\mathrm{PtCl}_{2}(\mathrm{MA})$ (pip-pip)] $\cdot \mathrm{HCl}$ are depicted in Figure 2. Structurally, the complexes can be divided to four moieties: the planar diaminedichloroplatinum(II) coordination sphere comprising N1, N3, Pt1, Cl1, Cl2; the first ring of the nonplanar piperidinopiperidine ligand, which is bound directly to the Pt $(\mathrm{N} 1, \mathrm{C} 1-\mathrm{C} 5)$; the second piperidine ring, which is further removed from the metal center $(\mathrm{N} 2, \mathrm{C} 6-\mathrm{C} 10)$; the ligand that is trans to the pip-pip. The platinum coordination spheres,
Table 1. Important Bond Lengths and Angles for trans-[ $\left[\mathrm{PtCl}_{2}\left(\mathrm{NH}_{3}\right)\right.$ (pip-pip)] $\cdot \mathrm{HCl}$ and trans- $\left[\mathrm{PtCl}_{2}\left(\mathrm{CH}_{3} \mathrm{NH}_{2}\right)\right.$ (pip-pip) $] \cdot \mathrm{HCl}^{a}$

\begin{tabular}{|c|c|c|c|}
\hline \multicolumn{4}{|c|}{$\begin{array}{l}\text { Important Bond Lengths, Bond Angles, } \\
\text { and Torsion Angles for } 1\end{array}$} \\
\hline \multicolumn{4}{|c|}{ Bond Lengths, $\AA$} \\
\hline $\mathrm{Cl}(1)-\mathrm{Pt}(1)$ & $2.307(3)$ & $\mathrm{N}(1)-\operatorname{Pt}(1)$ & $2.08(1)$ \\
\hline $\mathrm{Cl}(2)-\mathrm{Pt}(1)$ & $2.321(3)$ & $\mathrm{N}(3)-\operatorname{Pt}(1)$ & $2.05(1)$ \\
\hline \multicolumn{4}{|c|}{ Bond Angles, deg } \\
\hline $\mathrm{N}(3)-\operatorname{Pt}(1)-\mathrm{N}(1)$ & $176.3(4)$ & $\mathrm{N}(3)-\operatorname{Pt}(1)-\mathrm{Cl}(1)$ & $89.5(4)$ \\
\hline $\mathrm{N}(3)-\mathrm{Pt}(1)-\mathrm{Cl}(2)$ & $88.6(3)$ & $\mathrm{N}(1)-\mathrm{Pt}(1)-\mathrm{Cl}(1)$ & $87.0(3)$ \\
\hline $\mathrm{N}(1)-\mathrm{Pt}(1)-\mathrm{Cl}(2)$ & $94.8(3)$ & $\mathrm{Cl}(2)-\mathrm{Pt}(1)-\mathrm{Cl}(1)$ & 178.1(1) \\
\hline \multicolumn{4}{|c|}{$\begin{array}{l}\text { Important Bond Lengths, Bond Angles, } \\
\text { and Torsion Angles for } 2\end{array}$} \\
\hline \multicolumn{4}{|c|}{ Bond Lengths, $\AA$} \\
\hline $\mathrm{Cl}(1)-\mathrm{Pt}(1)$ & $2.2966(7)$ & $\mathrm{N}(1)-\mathrm{Pt}(1)$ & $2.064(2)$ \\
\hline $\mathrm{Cl}(2)-\mathrm{Pt}(1)$ & $2.2920(8)$ & $\mathrm{N}(3)-\operatorname{Pt}(1)$ & $2.039(2)$ \\
\hline \multicolumn{4}{|c|}{ Bond Angles, deg } \\
\hline $\mathrm{N}(3)-\operatorname{Pt}(1)-\mathrm{N}(1)$ & $178.17(10)$ & $\mathrm{N}(3)-\mathrm{Pt}(1)-\mathrm{Cl}(1)$ & $91.76(8)$ \\
\hline $\mathrm{N}(3)-\mathrm{Pt}(1)-\mathrm{Cl}(2)$ & $87.12(8)$ & $\mathrm{N}(1)-\mathrm{Pt}(1)-\mathrm{Cl}(1)$ & $89.03(8)$ \\
\hline $\mathrm{N}(1)-\operatorname{Pt}(1)-\mathrm{Cl}(2)$ & $92.14(7)$ & $\mathrm{Cl}(2)-\mathrm{Pt}(1)-\mathrm{Cl}(1)$ & $177.75(3)$ \\
\hline
\end{tabular}

${ }^{a}$ Standard deviations are given in parentheses.
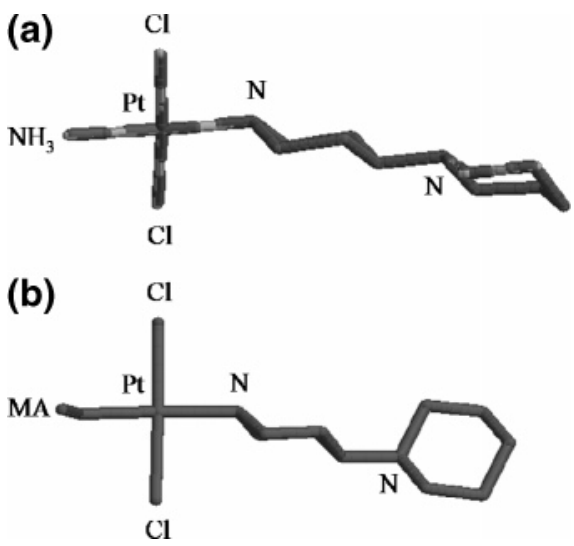

Figure 3. (a) Stick projection of the X-ray crystal structure of trans$\left[\mathrm{PtCl}_{2}\left(\mathrm{NH}_{3}\right)\right.$ (pip-pip)] $\cdot \mathrm{HCl}$ clearly showing that both piperidine rings are in the chair conformation. (b) Stick projection of the X-ray crystal structure of trans- $\left[\mathrm{PtCl}_{2}\left(\mathrm{CH}_{3} \mathrm{NH}_{2}\right)(\right.$ pip-pip) $] \cdot \mathrm{HCl}$ showing that the second piperidine ring can rotate relative to the first ring.

in both structures, are nearly square planar as indicated by the expected bond distances and bond angles that appear in Table 1.

The nonplanar piperidine rings can adopt either the chair or boat conformation. Both X-ray structures show that the two piperidine rings of the pip-pip ligand adopt the chair conformation. In principle, the Pt can bind to the first piperidine ring via the axial or equatorial positions around N1. In both structures the Pt binds to N1 via the equatorial position (Figures 2 and 3), probably in order to minimize steric repulsions. One obvious difference between the two structures is the torsion angles between the first and second piperidine rings that result from the rotation around the $\mathrm{C} 3-\mathrm{N} 2$ bond (Figure 3 ). The torsion angle $\mathrm{H} 3-\mathrm{C} 3-\mathrm{N} 2-\mathrm{H}(\mathrm{N} 2)$ for the trans- $\left[\mathrm{PtCl}_{2}\left(\mathrm{NH}_{3}\right)\right.$ (pip-pip)] $\mathrm{HCl}$ is $169.7^{\circ}$, while the same angle for the trans-[ $\mathrm{PtCl}_{2}(\mathrm{MA})-$ (pip-pip)] $\cdot \mathrm{HCl}$ is $64.4^{\circ}$. This indicates that, as might be expected, there is free rotation around the bond connecting the two piperidine rings, meaning that the proton attached to N2 can rotate in search of a hydrogen bond acceptor in its vicinity and adjust its position for optimal interaction. Because of crystallographic packing considerations, the lattice positions of the $\mathrm{Cl} 3$ couterions are different in the two structures (Figures 2 and 3), forcing different torsion angles between the two rings. 


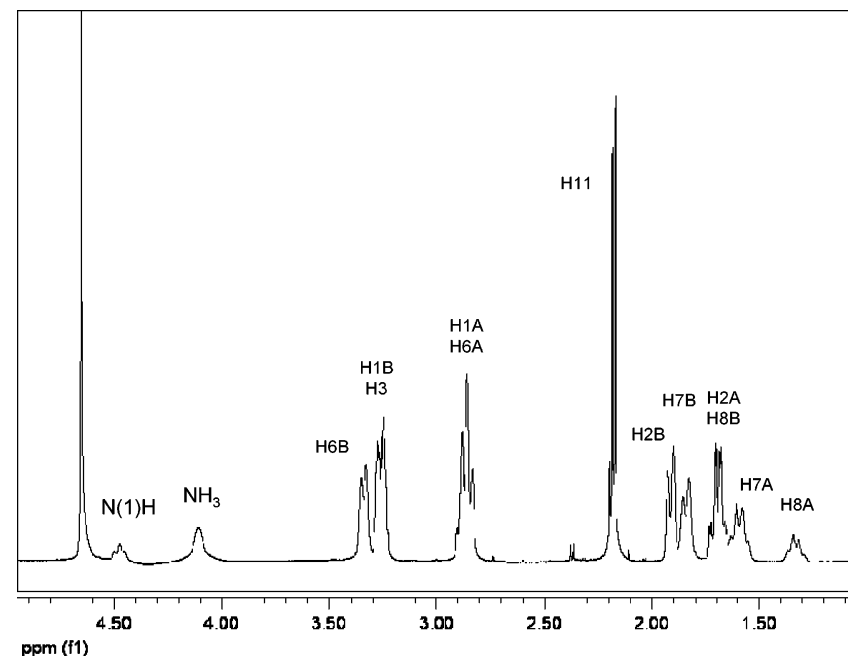

Figure 4. Proton NMR spectrum of trans- $\left[\mathrm{PtCl}_{2}\left(\mathrm{CH}_{3} \mathrm{NH}_{2}\right)\right.$ (pip-pip)] $\mathrm{HCl}$ showing the assignments of all protons.

Most of the other structural features of the two compounds are quite similar. Only some structural details for the MA complex (with the corresponding parameters for $\mathrm{NH}_{3}$ complex in parentheses) will be presented. The distance between the $\mathrm{Pt}$ and the protonated N2 is around $6.36 \AA(6.44 \AA)$. The cationic nature of the complex is evident from the crystal structure that shows that $\mathrm{N} 2$ is indeed protonated and that an additional chloride anion exists in the lattice in order to provide charge balance. There is a hydrogen bond between the chloride counterion $(\mathrm{Cl} 3)$ and the heterocyclic amine $(\mathrm{N} 2)$, which are separated by $3.06 \AA(3.10 \AA)$, and a $\mathrm{C} 2-\mathrm{N} 2-\mathrm{Cl} 3$ angle of $106.5^{\circ}\left(106.5^{\circ}\right)$. The distance between $\mathrm{Cl} 3$ and Pt1 is $7.96 \AA$ (7.47 $\AA$ ), the distance between $\mathrm{Cl} 2$ and $\mathrm{Cl} 3$ is $8.89 \AA(8.45 \AA)$, and $\mathrm{Cl} 3-\mathrm{Cl} 1$ is $7.65 \AA(7.22 \AA)$, demonstrating that upon monofunctional covalent binding of the complexes to the N7 of a guanine in ds B-DNA, the piperidinopiperidine ligand is capable of forming hydrogen bonds with hydrogen bond acceptors that are approximately two base pairs away from the platinum binding site.

NMR Spectroscopy. All the proton and carbon resonances of trans-[ $\mathrm{PtCl}_{2}\left(\mathrm{NH}_{3}\right)$ (pip-pip)] $\cdot \mathrm{HCl}$ and trans- $\left[\mathrm{PtCl}_{2}(\mathrm{MA})\right.$ (pippip) $] \cdot \mathrm{HCl}$ were assigned by a variety of NMR experiments that include ${ }^{1} \mathrm{H},{ }^{13} \mathrm{C}$, COSY, NOESY, HSQC, and HMBC. The labeling of the protons and carbons that appears in Figure 2 is used to describe the NMR results. The proton NMR spectrum is quite complex because of the magnetic inequivalence of the geminal methylene protons (on both piperidine rings) and because of the overlap of resonances from the two rings (Figure 4). trans-[ $\left[\mathrm{PtCl}_{2}(\mathrm{MA})(\right.$ pip-pip)] $\cdot \mathrm{HCl}$ has only seven resonances in the ${ }^{13} \mathrm{C}$ NMR spectrum (Supporting Information), indicating that in solution, the pip-pip ligand is symmetric. The assignment was done by first identifying the ${ }^{1} \mathrm{H}$ resonance of $\mathrm{H}(\mathrm{C} 3)$ from the cross-peak in the edited ${ }^{1} \mathrm{H},{ }^{13} \mathrm{C}$ HSQC spectrum (where $\mathrm{CH} /$ $\mathrm{CH}_{3}$ and $\mathrm{CH}_{2}$ peaks have opposite phases). Then, from the COSY, the ${ }^{1} \mathrm{H}$ resonance of $\mathrm{C} 2$ and $\mathrm{C} 1$ were identified. The $\mathrm{C} 8$ protons were assumed to resonate at the highest field, and they were used to assign the rest of the protons of the second piperidine ring from the COSY. The $\mathrm{NH}_{2}$ protons of the

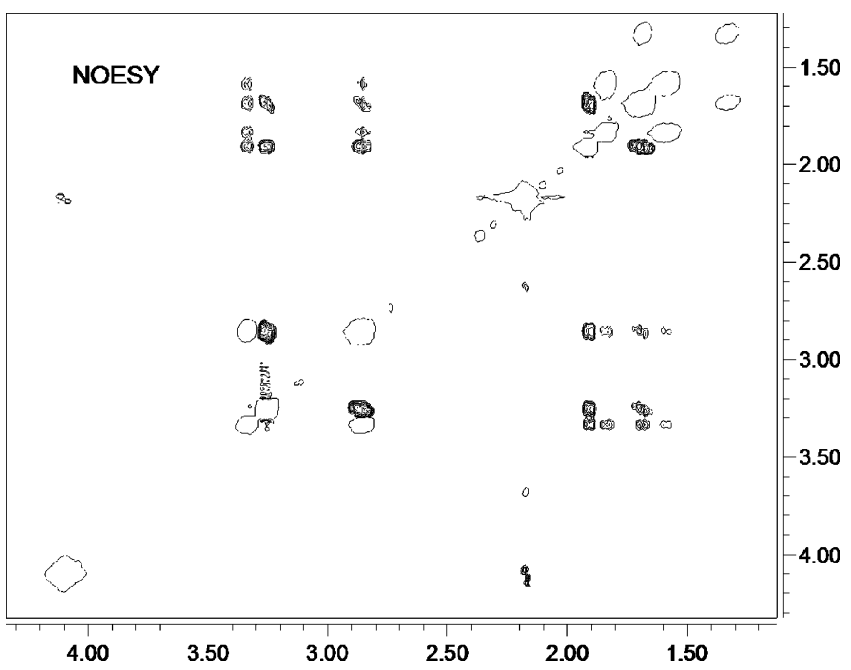

Figure 5. NOESY spectrum of trans- $\left[\mathrm{PtCl}_{2}\left(\mathrm{CH}_{3} \mathrm{NH}_{2}\right)(\right.$ pip-pip) $] \cdot \mathrm{HCl}$ showing the negative peaks in open circles and the positive peaks as contours. The cross-peaks of the second piperidine ring have the same phase as the diagonal peaks, testifying to the fluxionality of the second ring.

methylamine ligand and the $\mathrm{NH}$ proton of the first piperidine ring (bound to N1) were easily identified in the spectrum, but the $\mathrm{NH}$ proton of the second piperidine ring (bound to N2) was not observed because of fast exchange with the solvent (Figure 4). The carbons were assigned from the HSQC, and all the assignments were verified by HMBC. The assignments of all proton and carbon resonances appear in Table 2.

The most interesting feature of the NMR study is the NOESY spectrum that appears in the Figure 5. In phase-sensitive NOESY of small molecules, where the dominant relaxation mechanism is the double-quantum relaxation, the NOE cross-peaks are $180^{\circ}$ out of phase relative to the diagonal peaks. In the spectrum of trans $-\left[\mathrm{PtCl}_{2}\right.$ (MA)(pip-pip)] $\cdot \mathrm{HCl}$, the phases of all the crosspeaks of the first piperidine ring (protons 1-3) are opposite to those of the diagonal peaks while all the cross-peaks originating from the second piperidine ring (protons 6-8) have the same phase as the diagonal peaks (Figure 5). This indicates that the cross-peaks generated by the protons of the second piperidine ring are not NOE peaks but are exchange peaks, suggesting that the second ring is fluxional and its conformation is rapidly changing on the NMR time scale. This flexibility of the second piperidine ring was previously observed by us for trans- $\left[\mathrm{PtCl}_{2}-\right.$ $\left(\mathrm{NH}_{3}\right)$ (pip-pip)] $\cdot \mathrm{HCl}$ and corroborates the results obtained in the solid-state X-ray crystal structures. ${ }^{26}$

Interactions with DNA. One of the crucial events in the mechanism of action of platinum anticancer agents is the covalent modification of the DNA by the platinum complexes and the distortions conferred by this modification to the structure of the DNA. We chose to study the interactions of five complexes, trans-[ $\mathrm{PtCl}_{2}(\mathrm{Am})$ (pip-pip)] $\cdot \mathrm{HCl}$, where $\mathrm{Am}$ is $\mathrm{NH}_{3}$, MA, DMA, NPA, or NBA, with DNA. We were especially interested to see whether the large differences between the $\mathrm{IC}_{50}$ values of the $\mathrm{NH}_{3}$ and MA complexes could be explained by differences in their interactions with DNA. The DNA binding studies were carried out according to methods as in our previous work. ${ }^{27-29}$ The results are summarized in Table 3 .

Table 2. Proton and Carbon Chemical Shifts Assignments for trans-[ $\mathrm{PtCl}_{2}\left(\mathrm{CH}_{3} \mathrm{NH}_{2}\right)$ (pip-pip) $]^{+}$

\begin{tabular}{|c|c|c|c|c|c|c|c|c|c|c|}
\hline & \multicolumn{10}{|c|}{ position } \\
\hline & N1 & $\mathrm{C} 1$ & $\mathrm{C} 2$ & $\mathrm{C} 3$ & $\mathrm{~N} 2$ & C6 & $\mathrm{C} 7$ & $\mathrm{C} 8$ & N3 & $\mathrm{C} 11$ \\
\hline$\delta^{1} \mathrm{H}, \mathrm{ppm}$ & 4.48 & $2.87,3.27$ & $1.65,1.91$ & 3.25 & & $2.87,3.34$ & $1.59,1.85$ & $1.33,1.69$ & 4.12 & 2.19 \\
\hline$\delta^{13} \mathrm{C}, \mathrm{ppm}$ & & 49.9 & 26.7 & 61.7 & & 50.1 & 23.2 & 21.4 & & 32.6 \\
\hline
\end{tabular}


Table 3. Summary of DNA Binding Characteristics of trans- $\left[\mathrm{PtCl}_{2}\left(\mathrm{NH}_{3}\right)(\right.$ pip-pip) $]+\left(\mathrm{NH}_{3}{ }^{+}\right)$, trans- $\left[\mathrm{PtCl}_{2}(\mathrm{MA})(\text { pip-pip) }]^{+}\left(\mathrm{MA}^{+}\right)\right.$, trans-[PtCl $2(\mathrm{DMA})(\text { pip-pip) }]^{+}\left(\mathrm{DMA}^{+}\right)$, trans- $\left[\mathrm{PtCl}_{2}(\mathrm{NPA})(\text { pip-pip) }]^{+}\left(\mathrm{NPA}^{+}\right)\right.$, trans $-\left[\mathrm{PtCl}_{2}(\mathrm{NBA})(\text { pip-pip) }]^{+}\left(\mathrm{NBA}^{+}\right)\right.$, trans- $\left[\mathrm{PtCl}_{2}\left(\mathrm{NH}_{3}\right)(\right.$ piperidine $\left.)\right]$ $\left(\mathrm{t}-\mathrm{NH}_{3}, \mathrm{pip}\right)$, trans- $\left[\mathrm{PtCl}_{2}\left(\mathrm{NH}_{3}\right) \text { (piperazine) }\right]^{+}\left(\mathrm{t}-\mathrm{NH}_{3}, \mathrm{pz}^{+}\right)$, and Transplatin $\left(\mathrm{t}-\mathrm{NH}_{3}, \mathrm{NH}_{3}\right)$

\begin{tabular}{|c|c|c|c|c|c|c|c|c|c|}
\hline & cDDP & tDDP & $\mathrm{NH}_{3}+a$ & $\mathrm{MA}^{+a}$ & $\mathrm{DMA}^{+a}$ & $\mathrm{NPA}^{+a}$ & $\mathrm{NBA}^{+a}$ & $\mathrm{NH}_{3}$,pip ${ }^{b}$ & $\mathrm{NH}_{3}, \mathrm{pz}^{+b}$ \\
\hline DNA binding $t_{1 / 2},{ }^{c} \min$ & $120^{d}$ & $120^{d}$ & 13 & 15 & 20 & 14 & 18 & 113 & 20 \\
\hline $\mathrm{CD}$ band at $278 \mathrm{~nm}$ & inc $^{e}$ & $\mathrm{dec}^{e}$ & dec & inc & inc & dec & dec & inc & inc \\
\hline unwinding angle per adduct, deg & $13^{f}$ & $9^{f}$ & 30 & 30 & 30 & 30 & 15 & 30 & 15 \\
\hline $\begin{array}{l}\text { interstrand cross-linking, } \% \\
\text { melting temp }\left(\Delta t_{\mathrm{m}}\right)^{h}\end{array}$ & $6^{g}$ & $12^{g}$ & 26 & 27 & 26 & 20 & 20 & 26 & 18 \\
\hline low ionic strength, ${ }^{\circ} \mathrm{C}$ & $-2.5^{i}$ & $9.2^{i}$ & 14 & 11 & 6.1 & 9 & 9 & 7.6 & 7.9 \\
\hline high ionic strength, ${ }^{\circ} \mathrm{C}$ & $-4.1^{i}$ & $0.6^{i}$ & 1 & 5.9 & 3 & 5 & 5 & -1.9 & -1 \\
\hline
\end{tabular}

${ }^{a}$ This work. ${ }^{b}$ Reference $12 .{ }^{c}$ The time at which the binding reached 50\%. ${ }^{d}$ Reference 37. ${ }^{e}$ Reference $38 .{ }^{f}$ Reference $39 .{ }^{g}$ Reference $31 .{ }^{h} \Delta t_{\mathrm{m}}$ is defined as the difference between the $t_{\mathrm{m}}$ values of platinated and nonmodified DNAs. ${ }^{i}$ Reference 32.
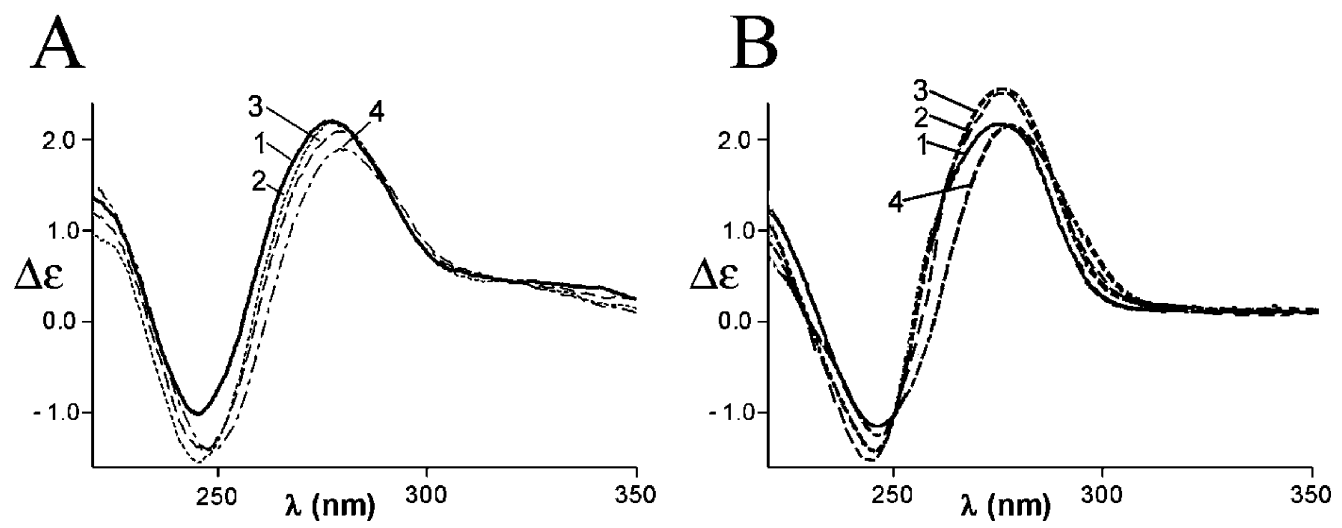

Figure 6. CD spectra of calf thymus DNA modified by trans-[ $\mathrm{PtCl}_{2}\left(\mathrm{C}_{3} \mathrm{H}_{7} \mathrm{NH}_{2}\right)\left(\right.$ pip-pip)] (A) or trans-[PtCl $2\left(\mathrm{C}_{2} \mathrm{H}_{5} \mathrm{NH} \mathrm{H}_{2}\right)($ pip-pip)] (B). CD spectra were recorded for DNA in $10 \mathrm{mM} \mathrm{NaClO}_{4}$ : (1) control (nonmodified) DNA; (2) $r_{\mathrm{b}}=0.03$; (3) $r_{\mathrm{b}}=0.05$; (4) $r_{\mathrm{b}}=0.1$ (in part A) or 0.08 (in part B).

Binding Rates to Calf Thymus DNA. All five complexes studied are significantly bulkier than cisplatin or transplatin, having molecular weights from 452 to 508 vs 300 for cisplatin (40-52 atoms vs 11 for cisplatin). Nevertheless, all the transplatinum complexes with the pip-pip ligand bound to calf thymus (CT) DNA significantly more quickly than cisplatin or transplatin. While the $t_{1 / 2}$ (the time it takes for $50 \%$ of the platinum complexes to covalently bind the DNA) for cisplatin and transplatin was $120 \mathrm{~min}$, the $t_{1 / 2}$ values for the pip-pip complexes were nearly an order of magnitude smaller, ranging from 13 to $20 \mathrm{~min}$ (Table 3). The rate-determining step for the platination of CT-DNA by cisplatin and transplatin is the aquation of the first chloride ligand to form the cationic [PtCl$\left.\left(\mathrm{H}_{2} \mathrm{O}\right)\left(\mathrm{NH}_{3}\right)_{2}\right]^{+}$, and then the aqua ligand is rapidly substituted by the N7 of the guanine on the DNA. Substitution reactions of square planar $\mathrm{Pt}(\mathrm{II})$ complexes proceed via an associative mechanism involving a sterically crowded trigonal bipyramidal intermediate, which accounts for the significantly slower substitution rates observed for complexes with bulky ligands. ${ }^{30}$

We have recently shown that trans- $\left[\mathrm{PtCl}_{2}\left(\mathrm{NH}_{3}\right) \text { (pip-pip) }\right]^{+}$ binds rapidly and directly to CT-DNA without prior hydrolysis, probably via an initial, rapid, electrostatically driven "preassociation" of the complex with the ds-DNA that positions the $\mathrm{Pt}$ in the correct orientation for direct substitution of the $\mathrm{Cl}$ by the N7 of the purines. ${ }^{26}$ The fact that the binding rates of the MA, DMA, and NBA complexes are very similar to that of trans$\left[\mathrm{PtCl}_{2}\left(\mathrm{NH}_{3}\right) \text { (pip-pip) }\right]^{+}$suggests that these complexes also bind CT-DNA in a similar fashion. There is only a slight reduction of the binding rates with increasing steric bulk of the ligand that is trans to the pip-pip, which is in line with the suggestion that the position of the charged N2 of the pip-pip relative to the $\mathrm{Pt}$ center is a dominating factor in facilitating the rapid DNA binding of these complexes.

The binding experiments of the present work indicate that the modification reactions resulted in the irreversible coordina- tion of the new analogues of transplatin to polymeric doublehelical DNA, which also facilitates sample analysis. Hence, it is possible to prepare easily and precisely the samples of DNA modified by the platinum complex at a preselected value of $r_{\mathrm{b}}$ $\left(r_{\mathrm{b}}\right.$ is defined as the number of molecules of the platinum compound bound per nucleotide residue). The samples of DNA modified by new platinum compounds and analyzed further by biophysical or biochemical methods were prepared in $10 \mathrm{mM}$ $\mathrm{NaClO}_{4}$ at $37{ }^{\circ} \mathrm{C}$. If not stated otherwise, after $24 \mathrm{~h}$ of the reaction of DNA with the complex the samples were precipitated in ethanol and dissolved in the medium necessary for a particular analysis and the $r_{\mathrm{b}}$ value in an aliquot of this sample was checked by FAAS. In this way, the analyses described in the present paper were performed in the absence of unbound (free) platinum complex.

Circular Dichroism Studies. CD spectral characteristics were compared for double-stranded CT DNA in the absence and in the presence of the pip-pip complexes at $r_{\mathrm{b}}$ values in the range of $0-0.1$. There was a decrease in the intensity of the positive band around $280 \mathrm{~nm}$ when the DNA was modified by trans$\left[\mathrm{PtCl}_{2}\right.$ (pip-pip) $\left.\left(\mathrm{NH}_{3}\right)\right] \cdot \mathrm{HCl}$, trans-[ $\left[\mathrm{PtCl}_{2}\right.$ (pip-pip)(NPA)] $\cdot \mathrm{HCl}$, or trans-[ $\mathrm{PtCl}_{2}$ (pip-pip)(NBA)] $\cdot \mathrm{HCl}$. The extent of this decrease was larger with increasing $r_{\mathrm{b}}$ values, behavior similar to that of transplatin (shown in Figure $6 \mathrm{~A}$ for trans-[ $\mathrm{PtCl}_{2}$ (pip-pip)(NPA)] $\mathrm{HCl}$ ). The decrease in the intensity of this band is attributed to denaturational changes in the double helix. When the DNA was modified by trans-[ $\mathrm{PtCl}_{2}$ (pip-pip)(DMA)] $\cdot \mathrm{HCl}$ or trans- $\left[\mathrm{PtCl}_{2}-\right.$ (pip-pip)(MA)] $\cdot \mathrm{HCl}$, there was an increase in the intensity of the positive band around $280 \mathrm{~nm}$ (shown in Figure 6B for trans$\left[\mathrm{PtCl}_{2}\right.$ (pip-pip)(DMA)] $\left.\mathrm{HCl}\right)$. The intensity of the increase was almost the same for $r_{\mathrm{b}}$ values of $0.01-0.05$, and only the highest $r_{\mathrm{b}}$ checked, 0.08, caused a decrease in the intensity to a level that was almost the same as that for unmodified CT DNA. This behavior is similar to that of cisplatin and is attributed to the 


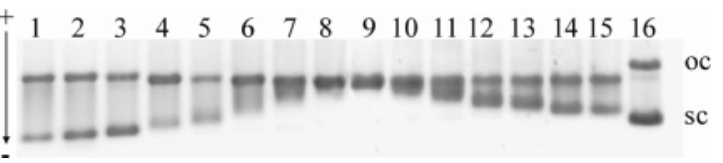

Figure 7. Unwinding of supercoiled pSP73 plasmid DNA modified by trans- $\left[\mathrm{PtCl}_{2}\left(\mathrm{C}_{3} \mathrm{H}_{7} \mathrm{NH}_{2}\right)\right.$ (pip-pip)]: $(1,16)$ control, nonplatinated DNA; (2) $r_{\mathrm{b}}=0.001 ;$; (3) $r_{\mathrm{b}}=0.005$; (4) $r_{\mathrm{b}}=0.01 ;$ (5) $r_{\mathrm{b}}=0.015 ;(6)$ $r_{\mathrm{b}}=0.02 ;(7) r_{\mathrm{b}}=0.025 ;(8) r_{\mathrm{b}}=0.03 ;$ (9) $r_{\mathrm{b}}=0.04 ;(10) r_{\mathrm{b}}=0.05$; (11) $r_{\mathrm{b}}=0.06 ;$ (12) $r_{\mathrm{b}}=0.07$; (13) $r_{\mathrm{b}}=0.08 ;$ (14) $r_{\mathrm{b}}=0.1 ;$; (15) $r_{\mathrm{b}}$ $=0.12$. The top bands correspond to the form of nicked plasmid (oc) and the bottom bands to closed negatively supercoiled plasmid (sc).

assumption that cisplatin causes nondenaturating changes in DNA, which appear as an increase in the positive CD.

To eliminate the possibility that the changes observed in the CD spectra result from their binding to the DNA bases rather than from structural changes to the double helix, we performed an experiment with denatured CT DNA. The thermally denatured DNA was incubated with the platinum complexes at $r_{\mathrm{b}}=$ $0.01-0.08$ for $24 \mathrm{~h}$ at $37^{\circ} \mathrm{C}$. There were no changes between the CD spectra of the denatured CT DNA before and after incubation with the platinum complexes, indicating that the changes observed were indeed due to structure changes in the double helix.

DNA Unwinding. A compound that unwinds the DNA duplex reduces the number of supercoils in closed circular DNA so that their number decreases. This decrease, due to binding of unwinding agents, reduces the rate of migration through agarose gel (shown for the NPA complex in Figure 7), which makes it possible to observe and quantify the mean value of unwinding per adduct. ${ }^{27-29}$ The values of unwinding angles are affected by the nature of the ligands in the coordination sphere of platinum and by the stereochemistry at the platinum center. The DNA unwinding angles resulting from the binding of platinum(II) compounds can be grouped into two main classes: small unwinding angles $\left(3-6^{\circ}\right)$ that are typical of complexes that can bind DNA only monofunctionally $([\mathrm{PtCl}($ dien $)] \mathrm{Cl}$ or $\left.\left[\mathrm{PtCl}\left(\mathrm{NH}_{3}\right)_{3}\right] \mathrm{Cl}\right)$; unwinding angles of $9-13^{\circ}$ that are associated with platinum compounds that bind to DNA in a bifunctional manner. The bifunctional binders include cisplatin $\left(13^{\circ}\right)$, transplatin $\left(9^{\circ}\right)$, and dinuclear complexes such as $[\{$ trans $-\mathrm{PtCl}-$ $\left.\left.\left(\mathrm{NH}_{3}\right)_{2}\right\}_{2}\left(\mu-\mathrm{H}_{2} \mathrm{~N}\left(\mathrm{CH}_{2}\right)_{n} \mathrm{NH}_{2}\right)\right] \mathrm{Cl}_{2}, n=2-6$. Interestingly, the unwinding angles produced by trans-[ $\mathrm{PtCl}_{2}(\mathrm{Am})$ (pip-pip)] complexes (Table 3 and Figure 7) are considerably higher than those produced by cisplatin or transplatin. One plausible explanation for this observation might be that the additional contribution to unwinding is associated with the interaction of the piperidinopiperidine group with the duplex upon covalent binding of platinum, indicating that the pip-pip is well positioned to interact with the double helix. The results of unwinding experiments support the view that the pip-pip ligand in these trans complexes interacts substantially with the double helix upon covalent binding of the platinum complex.

Interstrand Cross-Linking. Bifunctional platinum compounds that covalently bind to DNA form various types of interstrand and intrastrand CLs. Considerable evidence suggests that the antitumor efficacy of bifunctional platinum compounds is the result of the formation of these lesions, but their relative efficacy remains unknown. Therefore, we have decided to quantitate the interstrand cross-linking efficiency of all analogues of transplatin tested in the present work in the linearized 2464bp pSP73 plasmid modified by the platinum complexes. The samples were analyzed for the interstrand CLs by agarose gel electrophoresis under denaturing conditions. ${ }^{31}$ Upon electrophoresis, 3'-end labeled strands of linearized pSP73KB plasmid

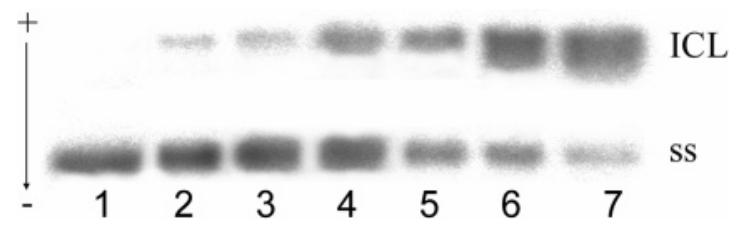

Figure 8. Formation of the interstrand CLs by trans- $\left[\mathrm{PtCl}_{2}\left(\mathrm{C}_{3} \mathrm{H}_{7} \mathrm{NH}_{2}\right)-\right.$ (pip-pip)] in pSP73 plasmid linearized by EcoRI. Shown is the autoradiogram of denaturing $1 \%$ agarose gels of linearized DNA, which was $3^{\prime}$-end labeled. The interstrand cross-linked DNA appears as the top bands (marked as ICL) migrating on the gel more slowly than the single-stranded DNA (contained in the bottom bands and marked as ss): (1) control, nonmodified DNA; (2-7) DNA modified by Pt-NPA; (2) $r_{\mathrm{b}}=0.00005 ;$; (3) $r_{\mathrm{b}}=0.0001$; (4) $r_{\mathrm{b}}=0.0003 ;$ (5) $r_{\mathrm{b}}=0.0005$; (4) $r_{\mathrm{b}}=0.0007 ;(5) r_{\mathrm{b}}=0.001 ;(6) r_{\mathrm{b}}=0.0015 ;$; (7) $r_{\mathrm{b}}=0.002$.

containing no interstrand CLs migrate as a 2464-base single strand, whereas the interstrand cross-linked strands migrate more slowly as a higher molecular mass species (Figure 8). The experiments were carried out with DNA samples that were modified by the platinum complexes for $24 \mathrm{~h}$ at various $r_{\mathrm{b}}$ values. The bands corresponding to the more slowly migrating interstrand cross-linked fragments were seen for $r_{\mathrm{b}}$ values as low as $5 \times 10^{-5}$ (shown for trans-[ $\mathrm{PtCl}_{2}\left(\mathrm{C}_{3} \mathrm{H}_{7} \mathrm{NH}_{2}\right)$ (pip-pip)] in Figure 8, lane 2). The intensity of the more slowly migrating band increased with the growing level of the modification. The radioactivity associated with the individual bands in each lane was measured to obtain estimates of the fraction of non-crosslinked or cross-linked DNA under each condition. The frequency of interstrand CLs (\% ICL/Pt) was calculated as described in the Experimental Section. The DNA interstrand cross-linking efficiency of all new analogues of transplatin tested in the present work was almost independent of $r_{\mathrm{b}}$ (the frequency of the CLs was in the range 20-27\%). Hence, the interstrand crosslinking efficiency found for the new analogues of transplatin was considerably higher than that found for parent transplatin $(12 \%) .^{31}$

Melting Temperatures. The values of melting temperatures $\left(t_{\mathrm{m}}\right)$ for the pip-pip complexes were obtained as previously described. ${ }^{30}$ The results appear in Table 3 indicating that at low ionic strength the complexes cause a significant stabilization of the double helix as indicated by an increase of the $t_{\mathrm{m}}$ by $6.1-14{ }^{\circ} \mathrm{C}$. At the high ionic strength, the increase of the $t_{\mathrm{m}}$ values was only in the range of $1-6{ }^{\circ} \mathrm{C}$. The effects of platination on the thermal stability of the DNA were attributed to several factors; the positive charge on the metal moiety and the formation of interstrand CLs contribute to the stabilization of the DNA (higher $t_{\mathrm{m}}$ ), while the destabilizing effects were attributed to conformational distortions such as intrastrand CLs induced by platinum coordination. An increase of $t_{\mathrm{m}}$ observed at low salt concentration (Table 3) can be interpreted to mean that under these conditions "stabilizing" effects such as interstrand CLs and positive charges on platinum moieties dominate over the "destabilizing" effects of conformational alterations induced by the adducts of trans-platinum compounds. ${ }^{32}$ That the adducts of new analogues of transplatin tested in the present work change the conformation of DNA is supported by the results of DNA unwinding and CD experiments (vide supra). An interesting question is why high salt concentration appears to result in lower overall stabilization due to the binding of the trans compounds. It is possible that the observed smaller increase in $t_{\mathrm{m}}$ at high ionic strength is a consequence of the smaller contribution of "stabilizing" effects of the adducts of transplatin analogues. At high salt concentration the stabilizing effects are reduced because electrostatic effects of the platinum compounds are apparently lowered with increasing concentration of $\mathrm{Na}^{+}$ 
Table 4. The $t_{1 / 2}(\mathrm{~min})$ for the Binding of the Platinum Complexes to $\mathrm{GSH}$ in $\mathrm{PBS}$ at $37^{\circ} \mathrm{C}$

\begin{tabular}{|c|c|c|}
\hline \multirow[b]{2}{*}{ Pt complexes } & \multicolumn{2}{|c|}{$\mathrm{Pt} / \mathrm{GSH}$ ratio } \\
\hline & $1: 1$ & $1: 5$ \\
\hline trans $-\left[\mathrm{PtCl}_{2}\left(\mathrm{MH}_{3}\right)\right.$ (pip-pip)] & $10 \pm 1.3$ & $4 \pm 0.4$ \\
\hline trans-[PtCl 2 (MA)(pip-pip)] & $11 \pm 1$ & $6 \pm 0.7$ \\
\hline trans- $\left[\mathrm{PtCl}_{2}(\mathrm{NBA})\right.$ (pip-pip)] & $16 \pm 1.5$ & $9 \pm 1.1$ \\
\hline trans-[PtCl 2 (NPA)(pip-pip)] & $18 \pm 1.5$ & $10 \pm 1.3$ \\
\hline trans-[PtCl 2 (IPA)(pip-pip)] & $19 \pm 1.3$ & $10 \pm 1$ \\
\hline trans-[PtCl 2 (DMA)(pip-pip)] & $22 \pm 1$ & $12 \pm 1.3$ \\
\hline transplatin & $28 \pm 3$ & $13 \pm 1.5$ \\
\hline trans- $\left[\mathrm{PtCl}_{2}(\mathrm{CHA})(\right.$ pip-pip) $]$ & $41 \pm 2.5$ & $22 \pm 1.3$ \\
\hline cisplatin & $1150 \pm 62.4$ & $600 \pm 66.1$ \\
\hline
\end{tabular}

counterions; nevertheless, the stabilizing factors still dominate over the destabilizing effects of conformational changes induced by their adducts. The melting of DNA modified by platinum compounds is a complex process that may involve other factors not considered in the present work.

Interactions of trans-[PtCl $\mathbf{2}(\mathbf{A m})($ pip-pip)] $\cdot \mathbf{H C l}$ Complexes with GSH. All the pip-pip complexes reacted with GSH significantly more quickly than cisplatin. The $t_{1 / 2}$ values of the 1:1 and 1:5 reactions of the Pt complexes with GSH are listed in Table 4 . The $t_{1 / 2}$ values in the pip-pip series correlated with the steric bulk of the Am ligands trans to the pip-pip. The ammine and methylamine are the fastest to react with $\mathrm{GSH}\left(t_{1 / 2}\right.$ $\approx 10$ and $11 \mathrm{~min}$ ) followed by the more bulky ligands NBA, NPA, IPA, and DMA (16-22 min) and finally by the CHA (41 min). The $t_{1 / 2}$ for cisplatin was measured at $1150 \mathrm{~min}$, which is more than 100 -fold slower than the ammine and methylamine complexes and about 25-fold slower than the CHA complex. Assuming that the substitution of the chloride ligand of the platinum complexes occurs via an associative mechanism with a pentacoordinate intermediate, then the steric bulk is expected to slow down the substitution rates and the $t_{1 / 2}$ values of the pip-pip complexes can be rationalized in terms of the molecular structure. It is true that because of the stronger trans effect of the chloride compared to the amine, it is expected that trans complexes will react more quickly than their cis counterparts. To separate the possible effects of charge and steric bulk from the trans effect, we measured the binding rates of transplatin to GSH. As can be see from Table 4 , the $t_{1 / 2}$ for transplatin is 28 min, which means that despite its lack of bulky ligands, it reacts with the GSH somewhat more slowly than the DMA complex but more quickly than the CHA. The fact that the much bulkier pip-pip complexes (except CHA) react with GSH more quickly than transplatin could be due to the positive charge on the ligand that may expedite the interaction with the negative charged GSH. Thus, the cationic charge of the ligand increases the binding rate to GSH relative to the neutral transplatin, but within the series of cationic complexes the bulkier the ligand that is trans to the pip-pip, the slower is the binding to GSH. When the reactions were carried out using a 1:5 ratio of $\mathrm{Pt} / \mathrm{GSH}$, a similar picture was obtained (see Table 4)

In the cytosol there is approximately 500- to 1000-fold excess of GSH relative to cisplatin (and other Pt drugs), which means that more than one GSH may bind to a given platinum complex. To study this possibility, increasing amounts of GSH were reacted with the platinum complexes and we followed the formation of $\mathrm{Pt}-\mathrm{S}$ bonds by $\mathrm{UV}$. The results are depicted in Figure 9. For all the complexes the UV absorption at $250 \mathrm{~nm}$ increased with the addition of GSH and leveled out after an amount of 2 equiv of GSH was added, indicating that under these conditions two GSH molecules were bound to each Pt center. To verify this finding, we have examined by the final products of the 1:1 and 1:5 reactions between the CHA complex

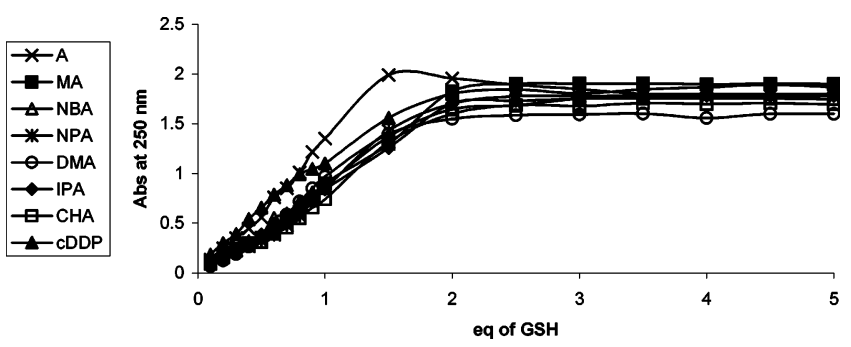

Figure 9. Binding of the pip-pip complexes to increasing concentrations of GSH.

and GSH by HPLC and by ${ }^{195} \mathrm{Pt}$ NMR spectroscopy. The HPLC chromatogram of the end of the 1:5 reaction showed a single peak at $\sim 14 \mathrm{~min}$ and a single resonance in the ${ }^{195} \mathrm{Pt} \mathrm{NMR}$ spectrum at $-3195 \mathrm{ppm}$ corresponding to trans-[Pt(GS) 2 (CHA)(pip-pip)]. The 1:1 reaction had two peaks in the HPLC chromatogram at 14 and $16 \mathrm{~min}$ and two peaks of equal intensity in the ${ }^{195} \mathrm{Pt} \mathrm{NMR}$ spectrum at -2874 and $-3195 \mathrm{ppm}$ (Supporting Information). This indicates that in the $1: 1$ reaction two products were formed: the 1:2 Pt/GSH complex trans-[Pt$(\mathrm{GS})_{2}(\mathrm{CHA})($ pip-pip)] and the $2: 1 \mathrm{Pt} / \mathrm{GSH}$ complex trans$\left\{\left[\mathrm{PtCl}(\mathrm{CHA})(\text { pip-pip) }]_{2}(\mathrm{GS})\right\}\right.$. It seems reasonable to conclude that it is very likely that when there is large excess of GSH relative to the platinum complex, like there is in the cell, the 1:2 Pt/GSH complex trans-[Pt(GS) 2 (Am)(pip-pip)] will dominate.

Interactions of trans-[ $\mathrm{PtCl}_{2}(\mathrm{Am})$ (pip-pip)] Complexes with Ub. The interactions of the pip-pip complexes with Ub were studied by ESIMS as previously described. ${ }^{33,34}$ All the complexes that formed a covalent bond with Ub formed 1:1 adducts with the protein. The mass of the adducts corresponded to the sum of the masses of the protein and the complex minus one chloride atom. This indicates monofunctional binding to the protein to yield trans-[PtCl(Ub)(Am)(pip-pip)]. From a chemical affinity point of view, the platinum complex has two preferred binding sites on Ub: Met1, which in slightly buried in the folded protein; His68, which is completely exposed on the surface. To determine the binding site of the complexes, we oxidized the protein with hydrogen peroxide in acetic acid, thereby selectively converting the Met1 thioether $\left(-\mathrm{CH}_{2} \mathrm{SCH}_{3}\right)$ into the sulfone $\left(-\mathrm{CH}_{2} \mathrm{SO}_{2} \mathrm{CH}_{3}\right)$, which is incapable of binding metal complexes. The complete conversion of the thioether to the sulfone was verified by ESIMS where the peak of the native $\mathrm{Ub}$ at $8656 \mathrm{amu}$ was completely converted to the peak of the oxidized Ub (UbOx) at $8688 \mathrm{amu}$. When the complexes were reacted with $\mathrm{UbOx}$, no covalent binding of the complexes to the protein was observed, indicating that the complexes bound exclusively to Met1. Thus, we conclude that the adducts that were formed were of the type trans-[PtCl(S-Met1-Ub)(Am)(pip-pip)]. It is interesting to note that over a 1 week period no translabilization/aquation of the chloride that is trans to the sulfur was observed, which would have resulted in the formation of another peak in mass spectrum that is $17 \mathrm{amu}$ less than the mass of the adduct.

The binding curves for cisplatin and the trans- $\left[\mathrm{PtCl}_{2}(\mathrm{Am})-\right.$ (pip-pip)] complexes with $\mathrm{Ub}$ are depicted in Figure 10. Contrary to what we observed with GSH, cisplatin binds to Ub significantly more quickly than the trans-pip-pip complexes. Within the trans-pip-pip series there are two groups of complexes: $\mathrm{NH}_{3}, \mathrm{MA}$, and DMA, which bind significantly more quickly than the NPA, IPA, NBA, and CHA complexes that show very little binding to the protein. This pattern of reactivity may be due to the fact that the NPA, IPA, NBA, and CHA ligands extend further away from the $\mathrm{Pt}$ center than do the $\mathrm{NH}_{3}$, 

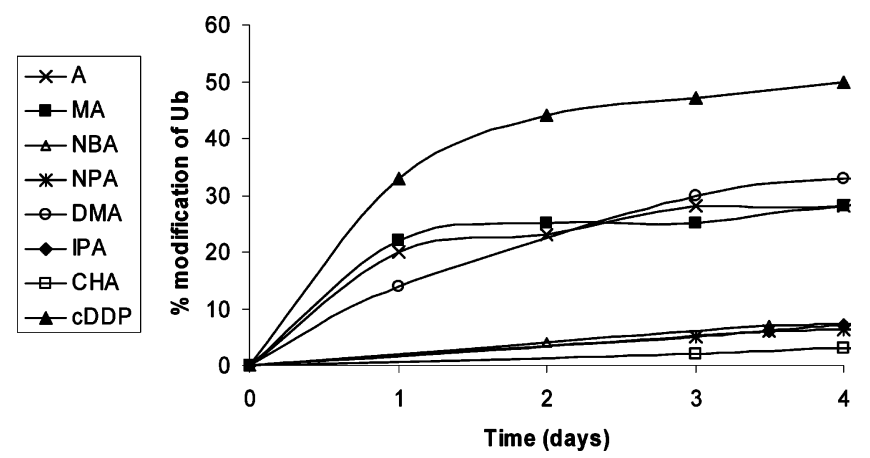

Figure 10. Binding curves of the pip-pip complexes to ubiquitin.

MA, and DMA ligands. Cisplatin, on the other hand, forms several types of adducts with $\mathrm{Ub}$ and does not bind exclusively to Met 1.35 These factors and its smaller size could be responsible for its much faster binding to the protein.

Since the binding of the complexes to Ub was monitored over nearly a week, we examined the stability of the protein over that time period. We measured the ESIMS of Ub in $100 \%$ water daily over a period of a week and obtained the identical spectrum with no sign of any type of deterioration. Ubiquitin is a tightly folded protein with 13 basic sites that can be protonated during the ESI process. When the protein is folded, only 7 or 8 sites are accessible to protonation. When the protein is denatured, up to 13 sites can be protonated, and by examination of the undeconvoluted ESIMS data, it is easy to deduce whether the protein is folded or denatured. We have examined the undeconvoluted data to look for any changes in the folding of the protein and found that the protein remained both intact and tightly folded during the entire week. The undeconvoluted spectra of the adducts were displayed on the +7 and +8 charge states, indicting that platination by these compounds did not result in denaturation of the protein.

\section{Discussion}

From the many studies that were carried out by several groups, it has become clear that the nature of the amine ligands in trans-diaminedichloroplatinum(II) complexes has a crucial impact on the cytotoxicity of the compound. The cytotoxicity is the resultant of many events, beginning with the cell accumulation and proceeding through detoxification by thiols, DNA modification, and cellular responses to the DNA damage. It is not a simple task, and it is probably incorrect to attribute the cytotoxicity of a given platinum complex to a single property of the compound. Nevertheless, it is important to explore how structural features of the platinum complexes affect the binding of the compounds to cellular nucleophiles such as proteins, peptides, DNA, etc. In the previous paper ${ }^{1}$ we have seen that trans- $\left[\mathrm{PtCl}_{2}\left(\mathrm{NH}_{3}\right)\right.$ (pip-pip)] $\cdot \mathrm{HCl}$ is twice as potent as trans$\left[\mathrm{PtCl}_{2}(\mathrm{MA})\right.$ (pip-pip)] $\cdot \mathrm{HCl}$ in two resistant cell lines $(\mathrm{CH} 1$ cisR and 41McisR), although they only differ by one methyl group. This could be due in part to the somewhat higher cellular accumulation and cellular DNA platination exhibited by trans$\left[\mathrm{PtCl}_{2}\left(\mathrm{NH}_{3}\right)\right.$ (pip-pip)] or perhaps due in part to differential interactions with cellular nucleophiles.

The structures of both compounds are essentially identical, and in both cases the pip-pip binds to the Pt through the equatorial position of the first pip ring and both piperidine rings adopt the chair conformation. Both X-ray crystallography and NMR studies indicate that for both complexes, the second pip ring is flexible, allowing it to optimize electrostatic and hydrogen bond interaction with anionic nucleophiles.
In terms of the binding kinetics to CT-DNA the cationic charge on the pip-pip is the dominant factor in determining the rate of covalent modification of the DNA. All the charged complexes bind to CT-DNA 6-10 times more quickly than the neutral cisplatin, transplatin, and trans- $\left[\mathrm{PtCl}_{2}\left(\mathrm{NH}_{3}\right)(\mathrm{pip})\right]$. We have recently shown that trans- $\left[\mathrm{PtCl}_{2}\left(\mathrm{NH}_{3}\right) \text { (pip-pip) }\right]^{+}$does not require hydrolytic activation for covalent modification of DNA. Since all the pip-pip complexes have very similar $t_{1 / 2}$ values for binding CT-DNA, we suggest that their binding to DNA proceeds via a rapid preassociation with the DNA that is followed by direct substitution of the chloride ligand by a purine. The unwinding angles of these nonsymmetric complexes are around $30^{\circ}$, which does not correspond to the typical values obtained for monofunctional adducts $\left(3-6^{\circ}\right)$ or bifunctional adducts $\left(9-13^{\circ}\right)$ but is similar to the angles reported for trans$\left[\mathrm{PtCl}_{2}\left(\mathrm{NH}_{3}\right)\right.$ (pip)] and trans- $\left[\mathrm{PtCl}_{2}\left(\mathrm{NH}_{3}\right)\right.$ (4-picoline) $]$, which contain only one heterocyclic ring. The higher unwinding angles were explained by the additional contribution to unwinding associated with the interaction of the heterocyclic ligand with the duplex upon covalent binding of platinum. It is interesting to note that for the more symmetric transplatinum complexes containing two heterocyclic rings, where the rings flank the platinum center as in trans- $\left[\mathrm{PtCl}_{2}\right.$ (4-picoline)(pip)] and trans$\left[\mathrm{PtCl}_{2} \text { (4-picoline)(pz) }\right]^{+}$, the unwinding angles are significantly lower $\left(13^{\circ}\right.$ and $\left.16^{\circ}\right)$ and closer to those yielded by cisplatin and its antitumor analogues. Thus, it is not only the volume of the complex that affects the unwinding angle but also the symmetry of the complex and the distribution of the bulk around the Pt. The DNA melting studies suggest that the binding of the pip-pip complexes to DNA stabilizes the double helix where the stabilization is more pronounced under low salt conditions. This indicates that both the positive charge of the ligand and the formation of interstrand CLs contribute to the stabilization of the double helix

On the basis of the results described, it seems that the unique structural features of the pip-pip ligand (positive charge and flexibility), as elucidated by X-ray crystallography and the NMR studies, are important in determining the DNA binding properties. On one hand, we attributed the very fast binding to CTDNA to the ability of the ligand to interact rapidly with the double helix prior to the covalent modification of the DNA (preassociation), while on the other hand the high unwinding angles and the $t_{\mathrm{m}}$ values indicate that the ligand interacts with the double helix after the covalent modification. Clearly the structural features of the pip-pip ligand facilitate rapid binding to CT-DNA and facilitate interactions with the double helix that result in the stabilization of the helix by electrostatic interactions and formation of interstrand CLs.

There are significant differences in the binding rates of the complexes to a thiol-containing tripeptide (GSH) and a small tightly folded protein having a thioether binding site (Ub). While cisplatin is the slowest to bind to GSH (by a factor of 100), it is the fastest binding complex to $\mathrm{Ub}$ and achieves the highest level of Ub modification. Also, the NPA, NBA, and IPA complexes bind to GSH more quickly than the DMA complex, but when it comes to binding to $\mathrm{Ub}$, the pattern is reversed and the DMA complex reaches $25 \%$ modification of the protein while the NPA, NBA, and IPA complexes hardly bind to Ub. We think that the main reason for these differences is the accessibility of the platinophile in GSH vs Ub to the Pt moiety. GSH is small and flexible and the $\mathrm{SH}$ is easily accessible to the Pt, while the Ub is tightly folded in solution and its Met1 thioether is less accessible, being slightly buried in the protein. Therefore, in the case of GSH, the steric bulk in the proximity 
of the Pt center (DMA, IPA) may be more effective in attenuating the reaction rates of the complexes because it interferes with the formation of the five-coordinate intermediate. In the case of Ub binding, where the thioether is less accessible, the Pt has to be able to get sufficiently close to the thioether to allow for bond formation. Complexes with the longer ligand span (NPA and NBA), in which the ligands extend further away from the platinum, are unable to position themselves in a way that allows the metal center to approach the thioether, probably because of the steric repulsion between the ligand and the protein surface. In the $\mathrm{NH}_{3}, \mathrm{MA}$, and DMA complexes, there is only a short extension trans to the pip-pip that allows for an effective interaction with the thioether. Thus, it is risky to use amino acids or small peptides as models for protein binding by $\mathrm{Pt}$ complexes. Moreover, since protein binding is probably strongly dependent on the accessibility of the platinophile, which in turn is dependent on the tertiary structure of the protein, it is very difficult to extrapolate the results from one protein to another or to generalize about "protein binding".

For Pt-Met adducts to be able to act as a reservoir for subsequent platination of DNA, the Pt-Met adducts have to be stable in the presence of GSH and should be able to form protein-Pt-DNA ternary complexes that transform to Pt-DNA adducts. We recently showed that $\mathrm{Ub}$ adducts with trans-[ $\left[\mathrm{PtCl}_{2-}\right.$ $(\mathrm{Am})($ pip-pip)]$\cdot \mathrm{HCl}$, trans-[Pt(Ub)Cl(Am)(pip-pip)], are not stable in the presence of GSH and react rapidly to form the ternary trans-[Pt(Ub)(GS)(Am)(pip-pip)] that proceed to degrade to produce the unplatinated native Ub. ${ }^{36}$ The ternary complexes with dGMP, trans-[Pt(dGMP)(Ub)(Am)(pip-pip)], form readily but are stable for long periods of time and do not release $\mathrm{Pt}-$ dGMP adducts. Moreover, the ternary Ub-Pt-dGMP complexes are quite stable in the presence of excess GSH. Despite the fact that the pip-pip complexes bind only to Met1 of Ub, the $\mathrm{Ub}-\mathrm{Pt}$ adducts are not able to safely transfer the Pt moiety to the DNA.

\section{Experimental Section}

X-ray Crystallography. Yellow crystals of approximate dimensions $0.2 \mathrm{~mm} \times 0.2 \mathrm{~mm} \times 0.1 \mathrm{~mm}$ were coated by epoxy glue, attached to the end of a glass fiber, and mounted on a Philips 1100/ 20 diffractometer. Mo $\mathrm{K} \alpha(\lambda=0.71069 \AA)$ radiation with a graphite crystal monochromator in the incident beam was used. The unit cell dimensions were obtained by a least-squares fit of 24 reflections in the range $11^{\circ}<\theta<15^{\circ}$. Data were measured by using an $\omega-2 \theta$ motion. Data were corrected for Lorentz and polarization effects. Intensity data were corrected for absorption using the empirical absorption program DIFABS, incorporated into TEXSAN (Single-Crystal Structure Analysis Software, version 5.0; Molecular Structure Corp., The Woodlands, TX, 1989). The heavy atoms were located by using the results of a SHELXS-86 directmethod analysis. Structure refinement was carried out with the fullmatrix least-squares program of TEXSAN. The structure was refined to convergence, using anisotropic thermal parameters for all non-hydrogen atoms. All crystallographic computing was done on a VAX 9000 computer at The Hebrew University of Jerusalem. Details of the crystallographic determination are given in the Supporting Information. Crystallographic data excluding structure factors for the structures reported in this paper have been deposited with the Cambridge Crystallographic Data Centre as supplementary publication number CCDC-266822 and CCDC 606085. Copies of data can be obtained, free of charge, on application to CCDC 12 Union Road, Cambridge CB2 1EZ, U.K. (fax, +44-(0)1223-336033; e-mail, deposit@ccdc.cam.ac.uk).

NMR Spectroscopy. All NMR studies were carried out on a Varian Inova $500 \mathrm{MHz}$ spectrometer equipped with either a $5 \mathrm{~mm}$ broadband probe or a $5 \mathrm{~mm}$ triple resonance probe. All the proton, carbon, and 2D experiments were measured in $\mathrm{D}_{2} \mathrm{O}$ using standard
VNMR software pulse sequences at $25^{\circ} \mathrm{C}$. The data were referenced externally to dixonae. All data were processed using the VNMR software; for the 2D spectra, a sinebell apodization was used in both dimensions for the absolute value experiments and $\cos ^{2}$ apodization was used in both dimensions for the phase-sensitive spectra. Linear prediction in the second dimension was applied. ${ }^{195} \mathrm{Pt}$ NMR spectra were processed with a $300 \mathrm{~Hz}$ line broadening and were referenced externally to $\mathrm{K}_{2} \mathrm{PtCl}_{4}(-1624 \mathrm{ppm})$.

Unwinding of Negatively Supercoiled DNA. The unwinding of closed circular supercoiled pUC19 plasmid DNA was measured by an agarose gel mobility shift assay. ${ }^{35}$ The unwinding angle, $\Phi$ induced per Pt-DNA adduct, was calculated upon the determination of the $r_{\mathrm{b}}$ value at which the complete transformation of the supercoiled to relaxed form of the plasmid was attained. Samples of pUC19 plasmid were incubated with platinum compounds for $48 \mathrm{~h}$, precipitated by ethanol, and redissolved in TAE buffer $(0.04$ $\mathrm{M}$ Tris-acetate $+1 \mathrm{mM}$ EDTA, $\mathrm{pH}$ 7.0). An aliquot of the precipitated sample was subjected to electrophoresis on $1 \%$ agarose gels running at $25^{\circ} \mathrm{C}$ in the dark with TAE buffer with a voltage set at $30 \mathrm{~V}$. The gels were then stained with ethidium bromide, followed by photography on Polaroid 667 film with a transilluminator. The other aliquot was used for the determination of $r_{\mathrm{b}}$ values by FAAS.

Interstrand Cross-Linking. Platinum complexes at varying concentrations were incubated for $24 \mathrm{~h}$ with $500 \mathrm{ng}$ of pSP73 DNA (2464 bp) linearized by EcoRI 3'-end labeled by means of the Klenow fragment of DNA polymerase I and $\left[\alpha-{ }^{32} \mathrm{P}\right] \mathrm{dATP}$. The platinated samples were precipitated by ethanol, the pellets were dissolved in $18 \mu \mathrm{L}$ of $30 \mathrm{mM} \mathrm{NaOH}$ with $1 \mathrm{mM}$ EDTA, $6.6 \%$ sucrose, and $0.04 \%$ bromophenol blue, and samples were immediately analyzed for platinum content by FAAS and for DNA interstrand CLs in the same way as described in recent papers. Briefly, the amount of interstrand CLs was analyzed by electrophoresis under denaturing conditions on alkaline agarose gel (1\%). After the electrophoresis was completed, the intensities of the bands corresponding to single strands of DNA and interstrand cross-linked duplex were quantified. The frequency of interstrand CLs, \% ICL/ $\mathrm{Pt}$ (the number of interstrand CLs per adduct), was calculated as $\% \mathrm{ICL} / \mathrm{Pt}=\mathrm{XL} / 4928 r_{\mathrm{b}}$ (EcoRI fragment of pSP73 plasmid contained 4928 nucleotide residues). XL is the number of interstrand CLs per molecule of the linearized DNA duplex, which was calculated by assuming a Poisson distribution of the interstrand CLs as $\mathrm{XL}=-\ln A$, where $A$ is the fraction of molecules running as a band corresponding to the non-cross-linked DNA.

DNA Melting. The melting curves of CT DNAs were recorded by measuring the absorbance at $260 \mathrm{~nm}$. The melting curves were recorded in a medium containing $10 \mathrm{mM}$ or $0.2 \mathrm{M} \mathrm{NaClO}_{4}$ with 1 $\mathrm{mM}$ Tris- $\mathrm{HCl} / 0.1 \mathrm{mM}$ EDTA, $\mathrm{pH}$ 7.4. The value of the $t_{\mathrm{m}}$ was determined as the temperature corresponding to a maximum in the first-derivative profile of the melting curves. The $t_{\mathrm{m}}$ values could be thus determined with an accuracy of $0.5^{\circ} \mathrm{C}$.

Reactions with GSH. The reactions of the Pt complexes with GSH were monitored by UV using an Ultraspec 2100 pro UV/ visible spectrophotometer with $1 \mathrm{~cm}$ quartz cells. The absorbance was monitored at $250 \mathrm{~nm}$ at $37^{\circ} \mathrm{C}$. The $1 \mathrm{mM}$ solutions of the complexes were prepared in $100 \mathrm{mM}$ PBS (pH 7.0). GSH solutions of $10 \mathrm{mM}$ (for the $1: 1$ reactions) or $50 \mathrm{mM}$ (for the $1: 5$ reactions) were prepared in $100 \mathrm{mM}$ PBS. The appropriate volumes of the complexes and GSH were mixed, and the reaction was monitored by UV.

Protein Binding Studies. Platination reactions were carried out at $1-2 \mathrm{mM}$ concentrations in $10 \mathrm{mM}$ phosphate buffer, $\mathrm{pH} 6.4$, at $37{ }^{\circ} \mathrm{C}$. Excess platinum was removed by ultrafiltration using Microcon YM-3 centrifugal filter devices at $4{ }^{\circ} \mathrm{C}$ and $12000 \mathrm{rpm}$, prior to all adduct reactivity studies. Protein binding profiles by ESIMS were measured directly on the reaction mixtures following ZipTip (C18, Millipore) treatment.

ESIMS was measured on a ThermoQuest Finnigan LCQ-Duo in the positive ion mode. In most cases, elution was in a mixture of 49:49:2 water/methanol/acetic acid at a flow rate of $15 \mu \mathrm{L} / \mathrm{min}$. 
Samples of the platination reactions and adduct reactivity studies were diluted by 100 -fold prior to ESIMS analysis. Data were processed using ThermoQuest Finnigan Xcalibur biomass calculation and deconvolution ESIMS software.

Acknowledgment. The research of J.K., P.H., and V.B. was supported by the Grant Agency of the Czech Republic (Grants $305 / 05 / 2030$ and 204/03/H016), the Grant Agency of the Ministry of Health of the Czech Republic (Grant NR8562-4/ 2005), the Ministry of Education of the CR (Grants MSMT LC 06030, 1P05OC070, 1P05OC072) and the Academy of Sciences of the Czech Republic (Grant 1QS500040581). J.K. is the International Research Scholar of the Howard Hughes Medical Institute. P.H. is supported by a doctoral fellowship from the Faculty of Sciences, Masaryk University, Brno, Czech Republic. The authors also acknowledge that their participation in the EU COST Action D20 enabled them to exchange regularly the most recent ideas in the field of platinum anticancer drugs with several European colleagues. D.G. acknowledges partial support from European COST D20/0003/00 Action and from the Israel Science Foundation (Grant 565/03). This study was supported in part by a Project Grant from Israel Cancer Research Foundation. J.M.P. thanks Spanish Ministry of Science and Education (Grant SAF2004-03111) for financial support.

Supporting Information Available: X-ray crystallographic data for trans-[ $\left[\mathrm{PtCl}_{2}\left(\mathrm{CH}_{3} \mathrm{NH}_{2}\right)\right.$ (pip-pip)] $\cdot \mathrm{HCl}$ and for trans- $\left[\mathrm{PtCl}_{2}\left(\mathrm{NH}_{3}\right)-\right.$ (pip-pip)] $\cdot \mathrm{HC}$ and 2D NMR spectra for the same compounds. This material is available free of charge via the Internet at http:// pubs.acs.org.

\section{References}

(1) Najajreh, Y.; Khazanov, E.; Jawbry, S.; Ardeli-Tzaraf, Y.; Perez, J. M.; Kasparkova, J.; Brabec, V.; Barenholz, Y.; Gibson, D. Cationic nonsymmetric transplatinum complexes with piperidinopiperidine ligands. Preparation, characterization, in vitro cytotoxicity, in vivo toxicity, and anticancer efficacy studies. J. Med. Chem. 2006, 49, $4665-4673$.

(2) Siddik, Z. H. Cisplatin: mode of cytotoxic action and molecular basis of resistance. Oncogene 2003, 22, 7265-7279.

(3) Wong, E.; Giandomenico, C. M. Current status of platinum-based antitumor drugs. Chem. Rev. 1999, 99, 2451-2466.

(4) Jamieson, E. R.; Lippard, S. J. Structure, recognition, and processing of cisplatin-DNA adducts. Chem. Rev. 1999, 99, 2467-2498.

(5) Fuertes, M. A.; Castilla, J.; Alonso, C.; Perez, J. M. Cisplatin biochemical mechanism of action: From cytotoxicity to induction of cell death through interconnections between apoptotic and necrotic pathways. Curr. Med. Chem. 2003, 10, 257-266.

(6) Fuertes, M. A.; Alonso, C.; Perez, J. M. Biochemical modulation of cisplatin mechanisms of action: Enhancement of antitumor activity and circumvention of drug resistance. Chem. Rev. 2003, 103, 645662.

(7) Chaney, S. G.; Campbell, S. L.; Bassett, E.; Wu, Y. Recognition and processing of cisplatin- and oxaliplatin-DNA adducts. Crit. Rev. Oncol. Hematol. 2005, 53, 3-11.

(8) Kartalou, M.; Essigmann, J. M. Mechanisms of resistance to cisplatin. Mutat. Res. 2001, 478, 23-43.

(9) Brabec, V.; Kasparkova, J. Molecular aspects of resistance to antitumor platinum drugs. Drug Resist. Updates 2002, 5, 147161.

(10) Momekov, G.; Bakalova, A.; Karaivanova, M. Novel approaches towards development of non-classical platinum-based antineoplastic agents: design of platinum complexes characterized by an alternative DNA-binding pattern and/or tumor-targeted cytotoxicity. Curr. Med. Chem. 2005, 12, 2177-2191.

(11) Brabec, V.; Kasparkova, J. Modifications of DNA by platinum complexes. Relation to resistance of tumors to platinum antitumor drugs. Drug Resist. Updates 2005, 8, 131-146.

(12) Kasparkova, J.; Marini, V.; Najajreh, Y.; Gibson, D.; Brabec, V. DNA binding mode of the cis and trans geometries of new antitumor nonclassical platinum complexes containing piperidine, piperazine, or 4-picoline ligand in cell-free media. Relations to their activity in cancer cell lines. Biochemistry 2003, 42, 6321-6332.

(13) Kasparkova, J.; Novakova, O.; Marini, V.; Najajreh, Y.; Gibson, D.; et al. Activation of trans geometry in bifunctional mononuclear platinum complexes by a piperidine ligand. Mechanistic studies on antitumor action. J. Biol. Chem. 2003, 278, 47516-47525.
(14) Boulikas, T.; Vougiouka, M. Cisplatin and platinum drugs at the molecular level. Oncol. Rep. 2003, 10, 1663-1682.

(15) Wang, D.; Lippard, S. J. Cellular processing of platinum anticancer drugs. Nat. Rev. Drug Discovery 2005, 4, 307-320.

(16) Tacka, K. A.; Szalda, D.; Souid, A. K.; Goodisman, J.; Dabrowiak, J. C. Experimental and theoretical studies on the pharmacodynamics of cisplatin in jurkat cells. Chem. Res. Toxicol. 2004, 17, 14341444.

(17) Appleton, T. G. Donor atom preferences in complexes of platinum and palladium with amino acids and related molecules. Coord. Chem. Rev. 1997, 166, 313-359.

(18) Reedijk, J. Why does cisplatin reach guanine-N7 with competing S-donor ligands available in the cell? Chem. Rev. 1999, 99, 24992510.

(19) Behrens, B. C.; Hamilton, T. C.; Masuda, H.; Grotzinger, K. R.; Whang-Peng, J.; Louie, K. G.; Knutsen, T.; McKoy, W. M.; Young, R. C.; Ozols, R. F. Characterization of a cis-diamminedichloroplatinum(II)-resistant human ovarian cancer cell line and its use in evaluation of platinum analogues. Cancer Res. 1987, 47, 414418.

(20) Kelland, L. R.; Abel, G.; McKeage, M. J.; Jones, M.; Goddard, P. M.; Valenti, M.; Murrer, B. A.; Harrap, K. R. Preclinical antitumor evaluation of bis-acetato-ammine-dichloro-cyclohexylamine platinum(IV): an orally active platinum drug. Cancer Res. 1993, 53, 25812586.

(21) Vrana, O.; Brabec, V. L-Methionine inhibits reaction of DNA with anticancer cis-diamminedichloroplatinum(II). Biochemistry 2002, 41 , 10994-10999.

(22) Marchan, V.; Moreno, V.; Pedroso, E.; Grandas, A. Towards a better understanding of the cisplatin mode of action. Chem.-Eur. J. 2001, 7, 808-815

(23) Marchan, V.; Pedroso, E.; Grandas, A. Insights into the reaction of transplatin with DNA and proteins: Methionine-mediated formation of histidine-guanine trans-Pt(NH3) 2 cross-links. Chem.-Eur. J. 2004, $10,5369-5375$.

(24) Barnham, K. J.; Djuran, M. I.; Murdoch, P. D.; Sadler, P. J. Intermolecular displacement of S-bound L-methionine on platinum(II) by guanosine $5^{\prime}$-monophosphate. Implications for the mechanism of action of anticancer drugs. J. Chem. Soc., Chem. Commun. 1994 $721-722$

(25) van Boom, S.; Chen, B. W.; Teuben, J. M.; Reedijk, J. Platinumthioether bonds can be reverted by guanine-N7 bonds in $\mathrm{Pt}(\mathrm{dien})^{2+}$ model adducts. Inorg. Chem. 1999, 38, 1450-1455.

(26) Najajreh, Y.; Prilutski, D.; Ardeli-Tzaraf, Y.; Perez, J. M.; Khazanov, E.; et al. Structure and unique interactions with DNA of a cationic trans-platinum complex with the nonplanar bicyclic piperidinopiperidine ligand. Angew. Chem., Int. Ed. 2005, 44, 2885-2887.

(27) Kasparkova, J.; Novakova, O.; Marini, V.; Najajreh, Y.; Gibson, D.; et al. Activation of trans geometry in bifunctional mononuclear platinum complexes by a piperidine ligand. Mechanistic studies on antitumor action. J. Biol. Chem. 2003, 278, 47516-47525.

(28) Prokop, R.; Kasparkova, J.; Novakova, O.; Marini, V.; Pizarro, A. M.; et al. DNA interactions of new antitumor platinum complexes with trans geometry activated by a 2-methylbutylamine or secbutylamine ligand. Biochem. Pharmacol. 2004, 67, 1097-1109.

(29) Brabec, V.; Kasparkova, J.; Vrana, O.; Novakova, O.; Cox, J. W.; et al. DNA modifications by a novel bifunctional trinuclear platinum phase I anticancer agent. Biochemistry 1999, 38, 6781-6790.

(30) Chen, Y.; Guo, Z. J.; Parkinson, J. A.; Sadler, P. J. Kinetic control of reactions of a sterically hindered platinum picoline anticancer complex with guanosine 5'-monophosphate and glutathione. J. Chem Soc., Dalton Trans. 1998, 3577-3585.

(31) Brabec, V.; Leng, M. DNA interstrand cross-links of trans-diamminedichloroplatinum(II) are preferentially formed between guanine and complementary cytosine residues. Proc. Natl. Acad. Sci. U.S.A 1993, 90, 5345-5349.

(32) Zaludova, R.; Kleinwachter, V.; Brabec, V. The effect of ionic strength on melting of DNA modified by platinum(II) complexes. Biophys. Chem. 1996, 60, 135-142.

(33) Peleg-Shulman, T.; Najajreh, Y.; Gibson, D. Interactions of cisplatin and transplatin with proteins. Comparison of binding kinetics, binding sites and reactivity of the $\mathrm{Pt}-$ protein adducts of cisplatin and transplatin towards biological nucleophiles. J. Inorg. Biochem. 2002, 91, 306-311.

(34) Najajreh, Y.; Shulman, T. P.; Moshel, O.; Farrell, N.; Gibson, D. Ligand effects on the binding of cis- and trans- $\mathrm{PtCl}(2) \mathrm{Am} 1 \mathrm{Am} 2$ to proteins. J.Biol. Inorg. Chem. 2003, 8, 167-175.

(35) Peleg-Shulman, T.; Gibson, D. Cisplatin-protein adducts are efficiently removed by glutathione but not by $5^{\prime}$-guanosine monophosphate. J. Am. Chem. Soc. 2001, 123, 3171-3172. 
(36) Balter, L.; Gibson, D. Mass spectrometric studies of the formation and reactivity of trans-[ $\mathrm{PtCl}_{2}(\mathrm{Am})$ (piperidinopiperidine) $] \cdot \mathrm{HCl}$ complexes with ubiquitin. Rapid Commun. Mass Spectrom. 2005, 19, $3666-3672$.

(37) Bancroft, D. P.; Lepre, C. A.; Lippard, S. J. Pt-195 NMR kinetic and mechanistic studies of cis-diamminedichloroplatinum and transdiamminedichloroplatinum(II) binding to DNA. J. Am. Chem. Soc. 1990, 112, 6860-6871.
(38) Brabec, V.; Kleinwächter, V.; Butour, J. L.; Johnson, N. P. Biophysical studies of the modification of DNA by antitumour platinum coordination complexes. Biophys. Chem. 1990, 35, 129-141.

(39) Keck, M. V.; Lippard, S. J. Unwinding of supercoiled DNA by platinum ethidium and related complexes. J. Am. Chem. Soc. 1992, $114,3386-3390$.

JM060238J 